DOI: https://doi.org/10.30525/978-9934-26-108-4-8

Yurii Radionov

Doctor of Economic Sciences, Head of the International Standards Adaptation and Implementation Department Accounting Chamber of Ukraine

ORCID: https://orcid.org/0000-0002-1691-1090

\title{
BUDGET PLANNING AS AN IMPORTANT FACTOR IN ENSURING ECONOMIC GROWTH
}

\section{Summary}

Budget planning is an important tool for effective management and use of budget funds. Given the limited financial resources, budget planning prevents waste, promotes economical use of budget funds, and the public administration system to fairly allocate financial resources to priority areas of economic, social, regional policy, to form a basis for sustainable economic development. The purpose of the study is to reveal the essence of budget planning as a tool for economic growth, highlight the existing problems in the budget planning system of Ukraine and find ways to improve and develop it. The study has found that in the structure of inefficient use of budget funds, a significant share falls on budget violations committed by participants in the budget process due to shortcomings in planning and lack of sound forecasting and planning. Thus, insufficiently effective budget planning is one of the reasons for inefficient management and use of budget funds. As a result, there is a causal link between the problems of budget planning and effective management and use of budget funds, which affects the dynamics of economic growth, the solution of socio-economic issues. It is noted that the programtarget method in modern conditions is a reliable lever to influence the efficiency and effectiveness of budget expenditures, which strengthens the budget's ability to form the basis of economic growth, as well as positively affects the effectiveness of fiscal policy in ensuring the welfare of citizens.

\section{Introduction}

Economic growth has significant shortcomings, especially the impact on the environment, excessive consumption and depletion of the earth's crust, while society is forced to increase social production.

As Fischer S., Dornbush R., and Schmalenzi R. note: «Material comfort is not everything but it is important to most people.» The strong desire of developing countries to grow economically is another proof that people usually want to have more goods and services [1, p. 656].

One of the ways to ensure economic growth, increase the output of goods and services is to increase the quantitative and qualitative indicators of 
economic activity, the focus of economic entities on the effectiveness of activities in each sector of the economy, efficient and rational use of natural, material and financial resources.

Budget policy is a significant lever of influence on the financial stability of the state, balanced economic development, increasing production, GDP growth, social protection. Its main task is to satisfy the population with the appropriate level of social standards, the appropriate amount of public goods, taking into account the balance of public finances, implemented through the institution of budget regulation, public financial control, ensuring sustainable dynamics of socio-economic development.

Budget regulation is a macroeconomic regulator of expanded reproduction aimed at achieving the goals and objectives of socio-economic development of the state, as it is an effective tool for regulating economic and social processes, because it justifies each use of budget expenditures taking into account the goals and objectives of socio-economic policy.

Budget planning is an important factor in regulating economic and social processes, the essence of which is to develop the main directions of budget expenditures and their direction in the medium and long term, taking into account the challenges facing society at the appropriate stage of its development. Budget planning forms the basis for sustainable economic growth, solving pressing socio-economic problems, taking into account the strategic goals of financial, budgetary and economic policy of the state. The development and implementation of budget policy priorities necessitates improving the quality of budget planning, strengthening the regulatory impact of budget expenditures on economic growth, building social infrastructure, improving living standards. Economic growth requires appropriate measures to balance the budget, increase the transparency of the budget process, improve inter-budgetary relations, complete budget execution at all levels, implement high-quality public financial control, including improving budget planning and efficient use of budget funds in priority areas of socio-economic development.

Among the important scientific researches of foreign scientists in the field of budget planning are the works of J. Buchanan, W. Nordhaus, P. Samuelson, J. Stiglitz and others. Current issues of budget formation and use of expenditures are studied in the works of domestic scientists: O. Vasylyk, A. Danylenko, N. Kornienko, L. Lysyak, V. Makogon, A. Myarkovsky, M. Tarasyuk, I. Chugunov and others. O. Vasylyk focuses on short-term tasks of budget planning, without rejecting the solution of this issue with socio-economic development. L. Lysyak, V. Makogon, I. Chugunov widely promote the introduction of program-target method of budget planning, although the researchers highlights their own vision and understanding of its application at all levels of the budget system. N. Kornienko considers the program-target method in the context of budget planning as a tool for achieving specific goals in the social and economic 
policy of the country. M. Tarasyuk emphasizes the importance of implementing strategic budget planning to address pressing issues of socioeconomic development of the country.

Despite the high level of theoretical and methodological developments, some works are debatable, further improvement of methods and techniques of budget planning in order to create conditions for the effectiveness of budgetary relations at the appropriate levels of government. In addition, most research focuses on individual budget planning tasks, while there is not enough scientific research on a comprehensive review of budget planning in the context of the integrity of the system with its problems and areas for improvement. In the current conditions of economic transformation, this issue becomes especially relevant due to the need to justify effective ways to achieve medium- and long-term goals in defense, educational, medical, investment, social, economic and other policies of the country. The formation of a comprehensive system of budget planning will contribute to the effectiveness of budget management, normalization of socio-economic indicators, ensuring sustainable dynamics of economic growth

The purpose of the study is to reveal the essence of budget planning as a tool for economic growth, highlight the problems of the budget planning system and find areas for further improvement.

The theoretical and methodological basis of the study were the works of domestic and foreign scientists, official documents, reports of the Accounting Chamber on the problems of budget planning and forecasting. The research used a set of methods of theoretical generalization, comparative analysis of the application of budget planning in Ukraine, analysis of the structure of inefficient management and use of budget funds, justification of ways to further improve budget planning as a tool for economic growth.

\section{Part 1. Theoretical and methodological principles of budget planning}

Budget planning is an important part of the country's financial system through which it is possible to determine the amount of budget revenues and expenditures, as well as the ways to attract and repay loans. This approach allows to implement a unified, balanced state policy, to adhere to the appropriate proportions of GDP distribution between sectors of the economy, administrative and territorial units, to provide financial resources for priority areas of socio-economic development.

In modern conditions, budget planning and forecasting plays a leading role in the formation and development of socio-economic structure of society, combining all areas of public finance: budget procurement management, public procurement, public debt, budget services, planning budget expenditures on investment projects and more. That is, there is a coherence in the form, timing, amount of budget funds within the budget system. At the macro level, the fiscal burden on the economy, the structure and the volume 
of public services and services provided to the population by the public sector is planned. Taking into account the strategic goals of the state, the tasks that are formed in the government's program priorities, budget plans, targeted state program activities are determined. That is, budget planning is one of the effective mechanisms to increase the level of validity of the use of budget expenditures.

Blagun I.G., Voronko R.M., Buchkovich M.L. believe that budget planning is a scientifically sound process of determining the sources of formation and directions of use of budget funds [2, p. 72].

According to Pasichnyk Yu.V., budget planning is the process of forming indicators of budget content by state legislative and executive bodies of a certain level for a specific period of time [3, p. 400].

Yaroshevich N.B., Shpak N.O., believe that budget planning is a set of organizational, technical and methodological measures to determine budget revenues and expenditures at all stages of the budget process [4, p. 60].

In our opinion, budget planning is a set of reasonable measures that are used in the budget process using different approaches, methods and techniques for determining the indicators of budget revenues and expenditures.

Budget planning is an important component of the financial resources management system to provide relevant consumers with the necessary and sufficient amount of budget funds. These funds are aimed at stimulating and financing the socio-economic development of administrative-territorial units while maintaining the conditions of financial stability, balanced budgets of all levels.

Budget revenue planning is carried out taking into account the fact that financial resources as part of the potential tax and non-tax revenues accumulated in the relevant budget, is an important component of a scientifically sound implementation of the budget process. The main priority of revenue planning is to ensure financial autonomy by filling the revenues of financial resources to the budgets of all levels. Budget expenditure planning is a set of methods and techniques aimed at determining the required amount of budget expenditures to the established parameters and commitments of budget policy, according to the approved priorities of socio-economic development of the country. The main areas of budget planning are: finding reserves of financial resources to meet government obligations and prioritize the use of budget expenditures.

Budget planning is formed on the basis of the principles of realism, predictability, transparency, publicity, scientific validity. This means that the budget should be based on real macroeconomic socio-economic indicators, predictability of fiscal policy, availability of information to the general public, analysis of the state of budget execution, achievement of planned performance indicators, elimination of shortcomings and miscalculations, 
evaluation of forecast models and factors of socio-economic development of the country.

Budget planning is a component of national socio-economic planning, which involves the joint activities of various participants in the budget process, i.e. government agencies, the public, which are involved in the formation and implementation of the budget. The subject of budget planning is funds, their movement, financing of industries, areas of economic development in the process of economic reproduction and economic growth.

In accordance with the functions performed by budget planning, its content is formed and filled. Thus, budget planning performs the following functions:

- identifies priority areas of socio-economic development;

- redistributes financial resources to various budget programs, projects and determines the rate of economic growth;

- contributes to improving the standard of living, well-being of citizens;

- reflects the essence of the country's budget policy.

Budget planning is based on the scientific principles of its organization, in particular:

- based on the potential of the budget, applies a comprehensive approach to the parameters of economic and social development of the country;

- focuses budget resources on current priority activities;

- identifies sources of revenue and redistributes them through the budget system;

- applies uniform methodological approaches to forecasting and development of socio-economic processes, calculations and determination of budget macro indicators;

- carries out on the basis of scientific calculations of plans and improves methods of budget planning.

In Ukraine, when carrying out budget planning, committees of the Verkhovna Rada of Ukraine, the Cabinet of Ministers of Ukraine, ministries and departments, consultants, international experts and financial institutions are involved in the process, which should take into account:

- basic principles of budget policy for the next budget period;

- separate programs of social and economic development of Ukraine;

- a set of legislative and regulatory acts adopted by resolutions of the Cabinet of Ministers of Ukraine, Decrees of the President of Ukraine, which affect tax policy and relate to the formation of budget revenues and expenditures, as well as key macroeconomic indicators, GDP growth, minimum wage, poverty, etc.;

- volumes of intergovernmental transfers and their distribution between regions;

- inflation rate;

- payment of debts on external and internal obligations of the state;

- other socio-political, economic factors that may affect the revenue and expenditure side of the budget. 
At the regional level, when implementing budget planning of the local budget, the following are taken into account:

- the main directions of socio-economic development of the city, town, village;

- projected indicators of the consolidated balance of budgetary resources of administrative and territorial units;

- investment development plans;

- the state of budget execution last year and the achieved socio-economic indicators.

It should be noted that budget planning must take into account all the negative factors that may affect the country's economy, disrupt the stability of its financial system. Ensuring effective budget planning is difficult, especially in a country with an unstable socio-economic, political situation and limited financial resources.

The need to use an effective tool of budget planning in Ukraine is caused by the specifics of socio-economic development of the state, as it is necessary to increase production, economic growth, GDP to ensure high living standards.

Qualitative budget planning makes it possible to stabilize the socioeconomic situation, direct the entire budget process in the right, scientifically sound direction, which will help the country get on the new rails of economic and social development, will ensure sustainable dynamics of economic growth.

In some foreign countries, budget planning is carried out for more than one year. For example, in France, multi-year planning is carried out for 3 years, in Germany and Sweden, planning is carried out for 5 years. This is due to national traditions in each country, and the budget period in each country does not start and end in the same way. For example, in Ukraine only from 2019 the three-year budget planning is introduced, and annually from January 1 to December 31 the budget year lasts and it coincides with the calendar, the situation is similar in some European countries, such as Italy, Belgium, the Netherlands.

Budget planning, which is carried out not for one year, but for the medium and long term, lays the foundation for long-term development with specific measures, deadlines, participation of various branches of government, local governments aimed at effectively solving problems of socio-economic development of the state.

Budget planning, depending on the tasks, is divided into: strategic, current, operational. Strategic planning involves the development of long-term plans for several years to come, as is the case, for example, in Germany and Sweden. Current budget planning involves the formation of financial plans for one year. Operational planning can include estimates of revenues and expenditures, allocation plans, budget schedule, i.e. those documents that ensure the implementation of budgets during one budget period. 
According to M.V. Tarasyuk, to solve the problem of coordination of strategic, tactical (medium-term) and operational budget planning is possible due to the introduction of an approach that is to justify medium-term budget indicators that will be part of the government action program based on longterm economic and social development programs. The author believes that the practice of strategic and medium-term budget planning should be enshrined in law not only at the national level, but also at the level of local communities [5, p. 26].

Planning is the tool by which the state not only regulates economic or social processes, but also influences regional and foreign economic policy, development of science, education, health care, stimulates business activity, encourages businesses to increase productive labor, and so on.

An important task of budget planning is:

- establishment of real sources of filling budgets of all levels;

- ensuring the efficient use of budget resources;

- fair distribution of funds between different administrative and territorial units;

- meeting the social needs of the population in each locality of the country;

- ensuring macroeconomic proportions of state development;

- creation of necessary social reserves, which are used for planned and unplanned activities;

- creation of transparent conditions for payments, movement of budget funds;

- the ability to exercise effective financial control over each budget program, project, financial transaction at all stages of the budget process.

In our opinion, it is important to increase the effectiveness of budget policy in terms of developing a budget planning system as a tool for economic growth, ensuring the effectiveness of budget expenditures. The current period of socio-economic development of Ukraine requires an in-depth understanding of the place and role of the budget in the economic system, creating conditions for the formation of a transparent budget process and, accordingly, effective budget planning.

Different methods are used in budget planning (Figure 1), for example: balance, provides for the coordination of budget revenues and expenditures, standards - the application of relevant norms, analytical - determination of budget indicators based on modeling, the method of coefficients is based on coefficients calculated by the ratio period to the planned indicators. However, there is one that has a certain feature in ensuring the efficient use of budget funds. This is widely known as a program-target method. The specificity of this method is that it ensures the rational use of financial resources, orients the participants of the budget process to achieve performance indicators, which is extremely relevant in the current conditions of socio-economic development of Ukraine. 


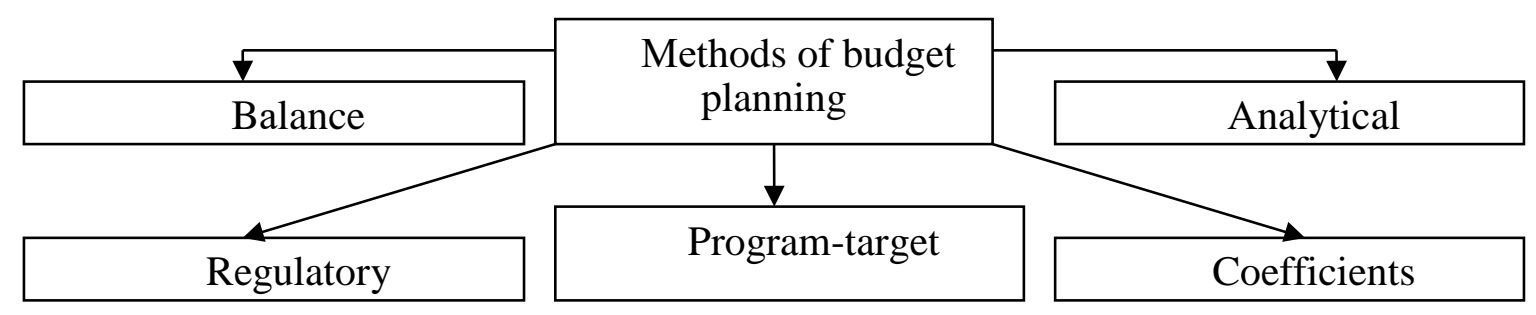

Figure 1. Methods of budget planning

Source: developed by the author

In addition, the program-target method differs from other methods of budget planning, as it allows to assess the effectiveness and efficiency of the use of budget funds.

Budget planning as a system includes: functions, purpose, tasks, object, subject, institutional and methodological support based on the legislative and regulatory framework. The functions of budget planning include the determination of exogenous and endogenous factors influencing the components of the budget system and its development. The purpose of budget planning is to form the preconditions for the stability and balance of the budget system. Tasks include: balancing budget indicators, macroeconomic proportions of the country's development, defining budget policy priorities and forming real, sound budget programs for their financing, promoting efficient allocation of budget expenditures, their targeted, effective use, ensuring optimal public goods and maximum approximation of guaranteed state social services to direct consumers.

Budget funds are the subject of planning, and state and local authorities are the entities that are obliged to effectively use the available financial resources.

Effective management of the budget process, in particular in the field of expenditures is a factor in the stability of the financial system, the key to sustainable economic growth.

In modern conditions, the budget carries a significant burden, as there is a need to meet the public goods, and on the other hand, limited financial resources of the budget do not allow for proper maneuvering, so effective budget planning plays an important role in allocating and using financial resources economy.

\section{Part 2. Problems of the budget planning system in Ukraine and development prospects}

Analyzing the state of budget planning in Ukraine, we conclude that the country has not created an effective system of sound budget planning for the economical and efficient use of financial resources, socio-economic development, economic growth. Thus, according to the Accounting Chamber in 2008 the largest weight in the structure of inefficient use of budget funds, namely 55.1 percent, were shortcomings in planning and lack of sound 
forecasting and planning (Figure 2). In 2009, this figure decreased by 10.2 percentage points and amounted to 44.9 percent. In 2010, compared to 2009, this figure decreased again by 34.2 percentage points and amounted to 10.7 percent. From 2010 to 2015, the indicator increased, except for 2014, because compared to 2013 it decreased by 9.4 percent and amounted to 25.6 percent. In 2016 and 2017, all violations were related to planning shortcomings. In 2018, on the contrary, all violations were related only to the lack of good forecasting and planning, which amounted to 3.3 percent, i.e. the figure decreased compared to 2017 by 1.8 percent point. It should be noted that from 2016 to 2018, the share of shortcomings in planning and the lack of sound forecasting and planning in the structure of inefficient use of budget funds was insignificant. However, in 2019 the structure of violations presented in the Report of the Accounting Chamber changed and violations committed in the planning of budget funds in the structure of violations of budget legislation amounted to 60.9 percent (of the total amount of $32,108.5$ million UAH) and in 2020 this figure was 17.1 percent.

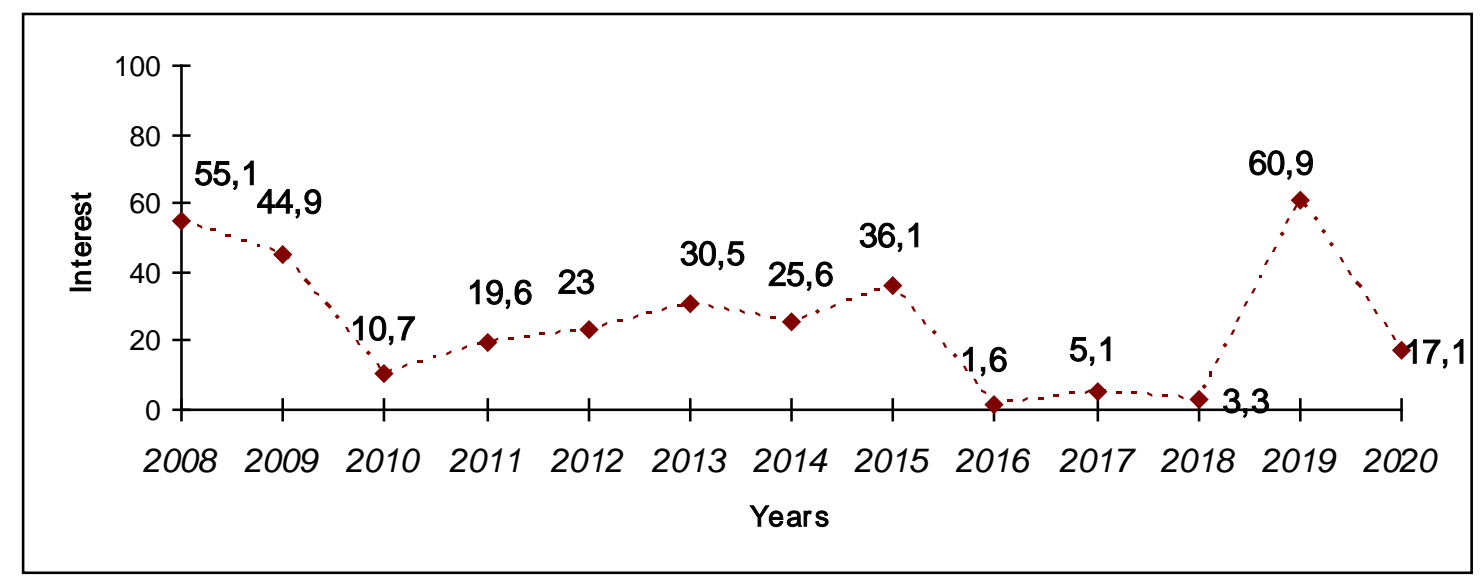

Figure 2. The total amount of identified facts in the structure of inefficient use of public funds due to shortcomings in planning and lack of sound forecasting and planning

Source: calculated by the author for [6-18]

We analyzed the total identified amounts of funds and the share of shortcomings in forecasting and planning in the structure of inefficient use of public funds, and noticed some discrepancies. For example, in 2008 there were facts of inefficient management and use of budget funds due to shortcomings in planning and lack of sound forecasting and planning for a total of 4 billion 321.1 million UAH (Figure 3). In 2009, this figure increased by 822.1 million UAH and amounted to 5,143.2 million UAH, although we see that the share in the overall structure of inefficient use of funds decreased by 10.2 percentage points. That is, the share in the overall structure of inefficient use of funds and the amount of identified amounts do not 
correspond to each other. A detailed analysis of the existing differences shows that everything depends on the established facts of violations, the amount and amounts of use of budget funds. Thus, in 2018 the total amount of identified budget funds due to shortcomings in planning amounted to 143.7 million UAH, and in 2019 this figure already amounted to 19552.2 million UAH, which is the largest amount for the entire period under study. However, in 2020 this figure descreased again and amounted to 2040.7 million UAH.

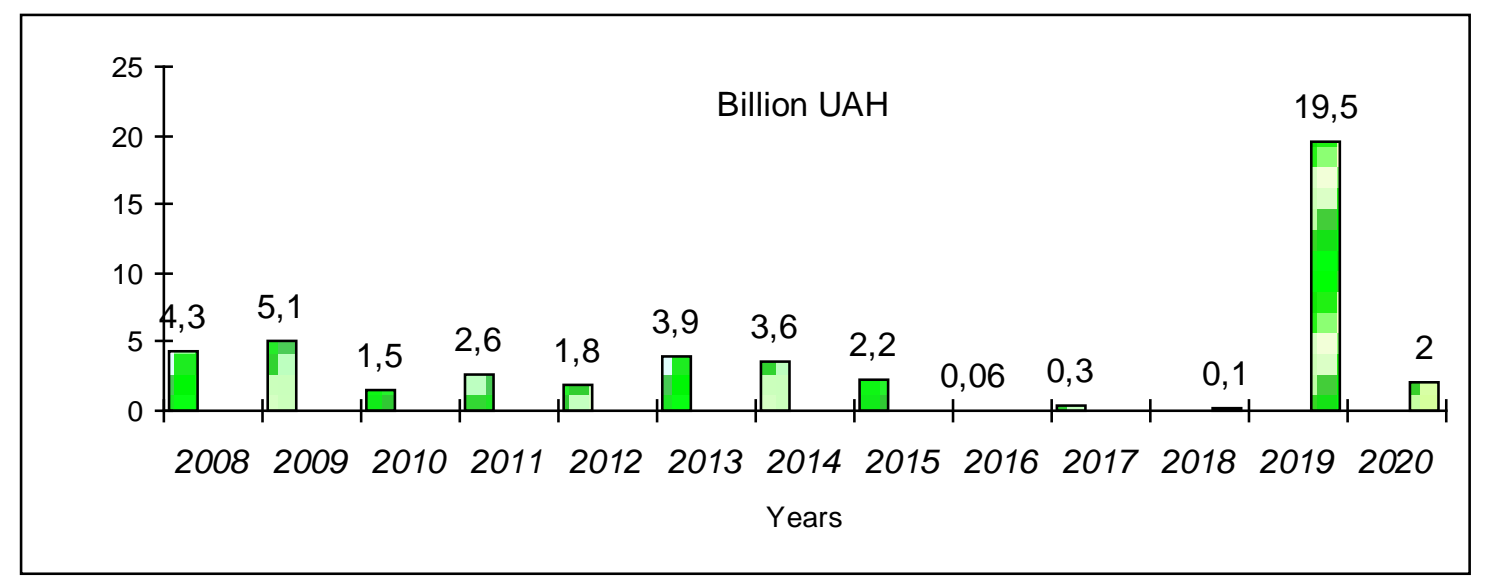

\section{Figure 3. The total amount of identified budget funds due to shortcomings in planning and lack of sound forecasting and planning}

Source: calculated by the author for [6-18]

Our analysis showed the urgency of the problem of budget planning in the use of budget funds. Fluctuations in the structure of inefficient management and use of budget expenditures indicate that this problem does not disappear over the years, on the contrary, it is replaced by other types of budget violations. At the same time, the identified amounts indicate that due to shortcomings in planning, budget expenditures are used inefficiently and, accordingly, constrain the dynamics of socio-economic development of the country, as the funds do not fulfill their tasks.

The study provides grounds for concluding that insufficiently effective budget planning is one of the reasons for inefficient management and use of budget funds. As a result, there is a causal link between the problems of budget planning and effective management and use of budget funds, which affects the dynamics of socio-economic development of the country, restrains economic growth.

It should be noted that the situation may change, as in Ukraine from January 10, 2019 with amendments to the Budget Code of Ukraine, in accordance with the Law of Ukraine dated December 6, 2018 No. 2646-VII «On approval of medium-term budget planning in Ukraine» [19] introduced medium-term budget planning. The medium-term budget period includes the planned and the next two planned budget periods. Instead of the one-year 
Main Directions of Budget Policy, the medium-term Budget Declaration has been introduced as a strategic planning document that defines the budget policy for the next three years. Three-year local financial plans will be a tool for medium-term budget planning at the local level. In our opinion, the provisions of medium-term budget planning will promote economic growth, development of society, determination of strategic directions of structural changes in the main sectors of the economy, balanced and consistent tax, debt, budget policy in the medium term.

The introduction of medium-term budget planning will allow the state to implement large-scale projects, the implementation period of which is five, ten years, i.e. those programs that go beyond one budget period. This will oblige participants in the budget process to substantiate the indicators of the planned budget year and take into account the obligations of the state in previous budget periods. With the introduction of medium-term budget planning, we hope that the dependence of the priorities of government agencies on the political situation will disappear, will make it impossible to waste budget funds and their inefficient use.

Medium-term budget planning corresponds to the principles on which the recommendations of the World Bank and the International Monetary Fund on the effectiveness of budget expenditure management are based [20; 21], in particular the fairness and efficiency of inter-budgetary relations, the introduction of the program-target method, the transparency of the budget process.

We hope that medium-term budget planning will contribute to the rational, efficient allocation and use of budget funds, as well as the balance of the budget and the budget system. The financial plan of each budget, depending on its level, performs tasks in a specific link of public administration. Qualitative drafting of the budget requires an appropriate level of interaction between state and local budgets, expenditures of all levels of the budget system, financial standards of budget security and coefficients that adjust them, settlement of fiscal legislation with determination of the appropriate level of tax burden on the economy, etc.

The formation of a multilevel system of budget planning will ensure the feasibility of justifying budget revenues and expenditures on the priority goals of social development.

The success of decentralization reform in Ukraine depends on high-quality budget planning, as will the indicators of the distribution of budgetary powers between the state and administrative and territorial units. That is, what level of public administration should provide funding for expenditures for certain functions of public authorities and local governments. The distribution of powers and the consolidation of financial resources in the budget planning system will be a prerequisite for the justification and implementation of economic and social development programs in the relevant territory. Fixing budget indicators for the medium term will strengthen the financial independence of local budgets, expand their capabilities, help develop 
mechanisms for investment attractiveness of regions, search for additional reserves of a particular area, development and implementation of promising budget programs that will form «growth points» of the economy.

It is important to choose methods, techniques and tools for modern monitoring and evaluation of budget programs, as well as to identify gaps and improve existing tools and methods to develop budget planning tools, its impact on the growth of economic and social indicators.

The efficiency of budget expenditures should be a priority of fiscal policy, which will provide an opportunity to form a basis for sustainable economic growth, increase the margin of stability of the socio-economic situation in the short and medium term.

In the implementation of budget planning institutional support is important, which is to create appropriate legislative, regulatory, organizational conditions for the functioning of the entire planning system. The effectiveness of the institutions of the planning system, as well as the economic system depends on the completeness of the institutions' compliance with modern realities and needs of society. Organizational and methodological principles are necessary for the preparation of budget requests, development of the draft budget taking into account the forecast indicators set by the Ministry of Finance for the next two budget periods.

It is important to harmoniously combine financial and economic, strategic and budgetary planning in order to address the priorities of society, to achieve significant indicators. Introduction of a comprehensive assessment of the implementation of budget programs and activities of authorities at all levels. Improving the budget process in order to form the transparency of each stage, accountability and control of public officials, the formation of an effective vertical of financial and economic, medium-term budget planning. This vertical presupposes a logical transition of public authorities and local self-government to the system of strategic planning as a basic tool for implementing policy in the economic and social spheres. Increasing the level of autonomy on the one hand, and on the other - the full responsibility of the government for the results of activities with clear quantitative and qualitative indicators of evaluation. Coordination of the action plan with the financial capabilities of the budget, rational use of budget resources, implementation of a reliable system of monitoring and control of the achievement of intermediate and final results of the goals of the strategy of socio-economic development of the country.

The use of modern methods and methods of medium-term budget planning allows to raise this tool to a better level, to ensure medium-term balance of budget revenues and expenditures, the formation of real, science-based budget programs with clearly defined priorities for socio-economic measures. This approach will significantly improve the quality of draft budget preparation, improve the budget process, evenly distribute appropriations by budget periods, introduce a system of economic incentives to optimize budget expenditures. 
It is important to coordinate the tasks of budget planning with the areas of socio-economic development of the country, which will significantly strengthen the role of budget planning in solving the tasks, taking into account the tax potential of the country and its territories. On the basis of budget forecasting as a base of planned indicators, conditions, tendencies, contradictions and alternatives of achievement of the strategic purposes of development of economy, social sphere are defined. Forecasting makes it possible to form an idea of the impact of endogenous and exogenous factors on socio-economic development, anticipate risks and avoid negative consequences in the future.

The relevance of budget forecasting lies in the relationship of macroeconomic indicators with budget architecture. Budgetary parameters and macroeconomic policy are influenced by a set of institutional measures, the structure of the country's economy, monetary policy. Budget forecasting is a means of substantiating the directions of budget policy development, the basis for focusing the efforts of authorities at all levels on the prospects of budgetary regulation of the economy. Budget forecasting is the basis for drafting state and local budgets, its indicators are used to develop a forecast of socio-economic development of the country in terms of administrative and territorial units and the same forecast is the basis of budget forecasting. Its main task is to substantiate the sources of filling the budget, finding an effective mechanism for implementing the tasks of budget policy, assessing possible risks, identifying priority areas for the use of budget funds. The process of budget forecasting is carried out continuously, so it requires constant refinement of budget indicators and its comparison with the dynamics of socio-economic development of the country.

Budget planning is the basis of financial planning with the definition of sources, amounts, and directions of use of budget allocations at all levels of government: state, regional, municipal, district, rural, and connects forecasts of macroeconomic indicators with budget revenues and government expenditures proposals.

There is a need for continuous improvement of methods and tools of budget forecasting, because in modern conditions it is advisable to improve the provision of budget services, and therefore forecasting should have a science-based basis based on anticipation of factors and disclosure and knowledge of phenomena affecting budget indicators.

In our opinion, the difference between forecasting and planning is that forecasting makes it possible to see the goal in the long run, including possible risk and impact factors. Planning is the reality we see before us, a more concrete and predictable phenomenon. If the prognosis is some probabilistic nature of action, then planning is a decision that has already been made, which brings us closer to the appropriate goal. Forecasting and planning are not antagonists, on the contrary, these concepts complement each 
other and ensure the continuity of the process of efficient and rational use of budgetary resources [22, p. 43].

Mechanism of budget forecasting in Ukraine needs to be improved, in particular, systematic analysis of assessments of socio-economic development of the country, identification of negative trends, analysis of the reasons for their formation, expansion of tools to influence negative processes that constrain the dynamics of socio-economic development

In modern conditions, it is impossible to achieve success in the socioeconomic sphere if the government, ministries do not plan their activities, constantly collecting and analyzing information on changes in foreign and domestic markets, make long-term forecasts to justify plans for further action of the government authorities.

According to A.I. Danylenko, in many countries, in one form or another, used planning elements do not create obstacles to using the positive aspects of the free market [23, p. 5].

According to Vasylyk O.D., in modern conditions the structure of the purposes of social and economic development and its relation to financial structures has been considerably complicated; changes in the financial potential of the state by sources, structure and dynamics continue. This requires new approaches and methodological solutions in the implementation of financial planning and forecasting [24, p. 118].

Only forward-looking forecasting makes it possible to effectively use limited budgetary resources for the priority goals of socio-economic development, ensuring financial stability, sustainable economic growth

For the successful development of society, the implementation of long-term strategy requires a qualitatively new system of budget forecasting as a scientifically sound process based on knowledge and prediction of objective and subjective factors that affect budget indicators and their quantification [25, p. 317-318].

Perspective forecasting of budget expenditures is an important tool for state regulation of economic and social processes, as it justifies the use of budget funds in the future, taking into account the identified goals and priorities of socioeconomic development of the state in the medium and long term [26, p. 71].

It is advisable to deepen the relationship between annual and long-term budget planning. When developing promising areas of fiscal policy, it is necessary to take into account the effect and reorientation of the economy to mainly endogenous factors of economic growth. It is important to introduce medium-term indicative planning in the activities of the main managers of budget funds [27, p. 8].

Budget planning as a tool for managing budget funds provides an opportunity to identify alternative ways to solve socio-economic problems, promotes openness, transparency in management decisions, accountability of government to society. 
The development of long-term budget policy should be based on the institutional development of the country, the inconsistency of its results with the established goals is a consequence of insufficient consideration of the institutional environment of society [28, p. 218].

To ensure sustainable development dynamics, significant institutional changes are needed in the system of financial and budgetary regulation of the economy, as their formation is carried out in the appropriate institutional environment and is a combination of components: intergovernmental relations, budget revenues and expenditures, deficit, public debt, tax regulation, external environment, internal economic processes in the country and their relationship. The institutional environment influences the transformation of the system of financial and budgetary regulation and its impact on the dynamics of economic growth.

Achieving strategic medium- and long-term goals of the country's development depends on taking into account in budget policy the peculiarities of the institutional environment of society, because budget architecture and qualitative characteristics of budget institutions affect the development of socio-economic processes. Therefore, the formation of a proper institutional environment of budgetary and economic space is an important factor in effective fiscal policy and promoting economic growth, improving the welfare of the population.

Perspective forecasting of budget expenditures is an important tool for state regulation of economic and social processes, as it justifies the use of budget funds in the future, taking into account the identified goals and priorities of socioeconomic development of the state in the medium and long term [29, p. 11].

According to Professor I.Ya. Chugunov, in the process of long-term budget planning, conditions are created for solving the most important tasks of state influence on economic development [30, p. 202].

In this context, it is important to note that long-term budget planning can be an important tool to prevent migration, create new jobs, improve birth rates, raise social standards, which will radically change the situation in the country in the long run, reveal domestic potential, ensure sustainable economic growth.

Any economic activity is carried out in a certain institutional model, which combines a set of different social, political, economic institutions mutually consistent with the traditions, culture, history of the people. This feature creates the institutional conditions for the formation and implementation of budget policy, including the use of budget funds.

Currently, the issue of efficiency of budget expenditures is one of the main tasks of the budget system. Given the limited budget funds, an important area is to improve the mechanism of expenditure management, increase their efficiency and effectiveness. Implementation of budget policy through a system of budgetary mechanisms should create a balance of the budget and have a positive impact on the processes of socio-economic development. The mechanism of forming the structure and volume of budget revenues and 
the formation of expenditures is an important component of budget regulation and economic growth.

The use of the state budget as an effective tool of macroeconomic regulation should be based on a prudent policy to ensure compliance with the growth rate of budget expenditures to the growth rate of the domestic economy, the implementation of budget programs aimed at eliminating infrastructure constraints in the economy. Improving the competitiveness of the country's economy, the quality of public services, living standards requires the implementation of a strategy to optimize budget expenditures while increasing their effectiveness. Not all types of expenditures have an equally positive impact on economic growth. So-called productive expenditures have a positive impact - expenditures of an investment nature, while investments are understood in a broad sense: they include investments in fixed capital, in human capital; such as education, health care. Consumer and social expenditures have less of an impact on economic growth [31, p. 125].

In our opinion, expenditures on health care and education do not guarantee better results if they are not accompanied by structural reforms aimed at improving the efficiency of the system and creating effective incentives, elements of feedback.

Budget funding for research contributes to scientific and technological progress, which has the opposite effect on the pace of socio-economic development, promotes economic growth.

Scientifically based definition of medium- and long-term goals of social development, qualitative and quantitative indicators of their implementation, taking into account the potential of the budget is a necessary condition for improving the quality of budget planning and strengthening its impact on economic growth. Development of real budget indicators taking into account the cyclical development of the economy, improve the quality of budget revenue and expenditure management, create preconditions for manageable budget process, positively affect the stability of the financial and budgetary system, the level of efficiency and effectiveness of budget policy, promote positive economic dynamics

In modern conditions of information technology development, it is appropriate to form a powerful information-analytical, methodological base that would simplify the budget planning process and would help participants in the budget process make timely, informed management decisions on the formation and use of budget resources.

It should be noted that in the framework of budget reform, in accordance with the Strategy for reforming the public financial management system for 20172020, «in terms of improving the program-target method, the order of the Ministry of Finance from 19.05.2020 № 223 'On assessing the effectiveness of budget programs of the state budget' came into force on July 24, 2020» [32]. This order provides for evaluation of efficiency at different stages of the budget process: planning, execution and reporting on budget execution; principles of 
monitoring the implementation of budget programs; obligation to monitor the measures of the budget program and performance indicators, for the implementation and achievement of which managers have made prepayment in previous budget periods; the form of presentation of the results of the evaluation of the effectiveness of the budget program for the reporting budget period; a list of issues that must be covered in the summary of the evaluation results; development of measures to increase the efficiency of the budget program for the medium term. The results of the evaluation for the reporting budget period are published by the main budget managers on their official websites. The implementation of this order, in our opinion, will promote transparency, accountability of public authorities, and the availability of information on the activities of budget managers will encourage participants in the budget process to increase measures for effective spending of budget funds. Evaluating the effectiveness of budget programs will strengthen the link with budget planning and should be an auxiliary tool in conducting reviews of budget expenditures and the responsibility of budget managers for their effective use.

\section{Conclusions}

According to the results of the study, the issue of budget planning is extremely relevant for the budget system of Ukraine, as a significant proportion of budget violations are committed in the field of budget planning and forecasting. Annual changes in the structure of inefficient management and use of budget funds prove that the problem of budget planning does not disappear over the years, on the contrary, it is replaced by other types of budget violations. At the same time, the amounts identified indicate that due to shortcomings in planning, budget expenditures are used inefficiently and, accordingly, restrain the dynamics of socio-economic development of the country, inhibit economic growth because the funds do not fulfill their tasks

The introduction of medium-term budget planning is a belated but positive step towards improving the efficiency of financial resources and achieving the strategic goals of socio-economic development of the country. Medium-term planning will contribute to the optimal tax and debt burden on business, the formation of the basis of economic growth, the stability of the macroeconomic environment. Medium-term planning of results of the budget focused on the result with definition of priorities in economic, social policy of the country is an important factor of economic growth, maintenance of efficiency of realization of economic policy of the country.

Budget planning affects the stability of the financial system, macroeconomic balance, the formation of the basis for sustainable economic growth. The issue of optimizing the budget deficit indicators in accordance with the tasks of the state economic policy, stimulating domestic demand, ensuring economic growth, and building infrastructure remains relevant. The main principles of budget expenditure planning should be integrity, soundness, consistency of financial indicators, balance of the budget system. 
It is important to optimize the size and structure of budget expenditures for the most effective, economical and effective mechanism for achieving the strategic goals of socio-economic development of the country

In modern conditions, it is advisable to improve the methodological basis of budget planning in monitoring the implementation of budget programs, achieving goals, objectives with determining the appropriate effect of the use of budget funds, both in the medium and long term.

It is necessary to use the advantages of the program-targeted method of budgeting in order to increase the level of efficiency of financial resources management, deepen the relationship between budget allocations and performance indicators of the budget, promote the effectiveness of budget policy. Mandatory annual evaluation of the effectiveness and efficiency of budget programs will strengthen the responsibility of participants in the budget process for the validity of appropriate indicators, definition of objectives, goals. It is important that each budget program meets the objectives and strategic goals of socio-economic development of the country.

It is advisable to create an information and methodological framework for management decisions in drafting a budget aimed at improving budget planning, improving management efficiency and use of financial resources of the country.

\section{References:}

1. Fisher S., Dornbush R., Shmalenzi R. (1997) Ekonomika [Economics]. Moscow: Delo. (in Russian)

2. Blagun I.G., Voronko R.M., Buchkovich M.L. (2017) Biudzhetnyi menedzhment [Budget managment]. Lviv: «Magnoliya-2006». (in Ukrainian)

3. Pasichnik Yu.V. (2008) Biudzhetna systema Ukrainy [Budget system of Ukraine]. Kyiv: Znannia. (in Ukrainian)

4. Yaroshevich N.B., Shpak N.O., Matviishin V.Ye. (2012) Biudzhetnyi menedgment [Budget managment]. Lviv: Vidavnitstvo Lvivskoi politehniky. (in Ukrainian)

5. Tarasyuk M.V. (2018) Biudzhetne planuvannia v Ukraini [Budget planning in Ukraine]. Visnyk KNTEU, no. 2, pp. 19-31.

6. Accounting Chamber of Ukraine (2009) Zvit Rakhunkovoi palaty za 2008 rik [Report of the Accounting Chamber of Ukraine for 2008]. Available at: http://www.ac-rada.gov.ua/ control/main/uk/publish/article/1497434 (accessed 10 June 2021).

7. Accounting Chamber of Ukraine (2010), Zvit Rakhunkovoi palaty za 2009 rik [Report of the Accounting Chamber of Ukraine for 2009]. Available at: http://www.ac-rada.gov.ua/ doccatalog/document/16741917/Zvit_2009.pdf (accessed 10 June 2021).

8. Accounting Chamber of Ukraine (2011), Zvit Rakhunkovoi palaty za 2010 rik [Report of the Accounting Chamber of Ukraine for 2010]. Available at: http://www.ac-rada.gov.ua/ doccatalog/document/16741918/Zvit_2010.pdf (accessed 12 June 2021).

9. Accounting Chamber of Ukraine (2012), Zvit Rakhunkovoi palaty za 2011 rik [Report of the Accounting Chamber of Ukraine for 2011]. Available at: http://www.ac-rada.gov.ua/ doccatalog/document/16740480/Zvit_2011.pdf (accessed 13 June 2021).

10. Accounting Chamber of Ukraine (2013), Zvit Rakhunkovoi palaty za 2012 rik [Report of the Accounting Chamber of Ukraine for 2012]. Available at: http:/www.ac-rada.gov.ua/ doccatalog/document/16742074/Zvit_2012.pdf (accessed 15 June 2021). 
11. Accounting Chamber of Ukraine (2014), Zvit Rakhunkovoi palaty za 2013 rik [Report of the Accounting Chamber of Ukraine for 2013]. Available at: http://www.ac-rada.gov.ua/ doccatalog/document/16744990/Zvit_2013.pdf (accessed 15 June 2021).

12. Accounting Chamber of Ukraine (2015), Zvit Rakhunkovoi palaty za 2014 rik [Report of the Accounting Chamber of Ukraine for 2014]. Available at: http://www.ac-rada.gov.ua/ doccatalog/document/16747166/Zvit_2014.pdf (accessed 10 June 2021).

13. Accounting Chamber of Ukraine (2016), Zvit Rakhunkovoi palaty za 2015 rik [Report of the Accounting Chamber of Ukraine for 2015]. Available at: http://www.ac-rada.gov.ua/ doccatalog/document/16748714/Zvit_RP_2015.pdf (accessed 10 June 2021).

14. Accounting Chamber of Ukraine (2017), Zvit Rakhunkovoi palaty za 2016 rik [Report of the Accounting Chamber of Ukraine for 2016]. Available at: http://www.ac-rada.gov.ua/ doccatalog/document/16751480/Zvit_RP_2016.pdf (accessed 18 August 2020).

15. Accounting Chamber of Ukraine (2018), Zvit Rakhunkovoi palaty za 2017 rik [Report of the Accounting Chamber of Ukraine for 2017]. Available at: http://www.ac-rada.gov.ua/ doccatalog/document/16755497/Zvit_RP_2017.pdf?subportal=main (accessed 10 June 2021).

16. Accounting Chamber of Ukraine (2019), Zvit Rakhunkovoi palaty za 2018 rik [Report of the Accounting Chamber of Ukraine for 2018]. Available at: http://www.ac-rada.gov.ua/ doccatalog/document/16760161/ZVIT\%20RP\%202018.pdf (accessed 10 June 2021).

17. Accounting Chamber of Ukraine (2020), Zvit Rakhunkovoi palaty za 2019 rik [Report of the Accounting Chamber of Ukraine for 2019]. Available at: https://rp.gov.ua/Activity/Reports/?id=876 (accessed 10 June 2021).

18. Accounting Chamber of Ukraine (2021), Zvit Rakhunkovoi palaty za 2020 rik [Report of the Accounting Chamber of Ukraine for 2020]. Available at: https://rp.gov.ua/Activity/Reports/?id=1083 (accessed 10 June 2021).

19. Law of Ukraine on approval of medium-term budget planning in Ukraine 2018. 9 Decemb. Available at: https://zakon.rada.gov.ua/laws/show/2646-19\#Text (accessed 10 June 2021).

20. Program budgeting is on the reform Agenda across Europe and Central Asia. Available at: http://blog-pfm.imf.org (accessed 10 June 2021).

21. Program classification for performance-based budgeting: how to structure budgets to enable the use of evidence. Available at: https://ieg.worldbankgroup.org (accessed 10 June 2021).

22. Radionov, Yu.D. (2014) Prohnozuvannia i planuvannia yak instrument efektyvnoho upravlinnia ta vykorystannia biudzhetnykh koshtiv [Forecasting and planning as a tool for efficient management and use of budgetary funds]. Ekonomika Ukrainy, no. 4, pp. 40-54.

23. Danilenko, A.I. 2013. Udoskonalennia modeli upravlinnia ekonomikoiu ta finansovi mehanizmy yii realizatsii [Improving the model of economic management and financial mechanisms for its implementation]. Ekonomika Ukrainy, no. 5, pp. 4-29.

24. Vasilik O.D. (2003) Teoriia finansiv [Finance theory]. Kyiv: NIOS. (in Ukrainian)

25. Makogon V.D. (2017) Biudzhetne prohnozuvannia yak instrument derzhavnoho rehuliuvannia ekonomichnykh protsesiv [Budget forecasting as a tool for state regulation of economic processes]. Biznesinform, no. 10, pp. 314-318.

26. Pavelko A.V., Chugunov I.Ya. (2015) Biudzhetna polityka ekonomichnoho rozvytku [Budget policy of economic development]. Visnyk KNTEU, no. 2, pp. 64-73.

27. Chugunov I.Ya., Pasichniy M.D. (2016) Finansova polityka Ukrainy v umovakh hlobalizatsii ekonomiky [Financial policy of Ukraine in the context of globalization of economics]. Visnyk KNTEU, no. 5, pp. 5-18.

28. Kornienko N.M. (2014) Perspektyvne biudzhetne planuvannia u systemi ekonomichnoho rozvytku [Perspective budget planning in the system of economical development]. Ekonomichnyi visnyk universitetu DVNZ «Pereiaslav-Khmelnytskyi derzhavnyi universitet imeni Hryhoriia Skovorody», no. 23/1, pp. 216-222. 
29. Myarkovskiy A.I., Chugunov I.Ya. (2010) Biudzhetna polityka yak skladova sotsialno-ekonomichnoho rozvytku krainy [Budget policy as component of the country's social and economical develoment]. Visnyk KNTEU, no. 5, pp. 5-15.

30. Chugunov I.Ya. (2005) Teoretychni osnovy systemy biudzhetnoho rehuliuvannia [Theoretical basics of the budget regulation system]. Kyiv: NDFI.

31. Kornienko N.M. (2016) Planuvannia vydatkiv derzhavnoho biudzhetu yak instrument sotsialno-ekonomichnoho zrostannia [State budget planning as a tool socioeconomical growth]. Prichornomorski ekonomichni studii, issue 12-2, pp. 123-128.

32. Order of the Ministry of finance of Ukraine on the evaluation of the effectiveness of budget programs of the state budget, 19 May. Available at: https://www.kmu.gov.ua/news/ minfin-zaprovadzhuye-novi-pidhodi-do-ocinki-efektivnosti-byudzhetnih-program (accessed 10 June 2021). 